The Psychology of American Racism

$$
\text { (in press - American Psychologist) }
$$

\author{
Steven O. Roberts ${ }^{1,2} \&$ Michael T. Rizzo ${ }^{3,4}$ \\ Department of Psychology, Stanford University ${ }^{1}$ \\ Center for Comparative Studies in Race and Ethnicity, Stanford University ${ }^{2}$ \\ Department of Psychology, New York University ${ }^{3}$ \\ Beyond Conflict Innovation Lab, Boston, Massachusetts ${ }^{4}$
}

(C) 2020, American Psychological Association. This paper is not the copy of record and may not exactly replicate the final, authoritative version of the article. Please do not copy or cite without authors' permission. The final article will be available, upon publication, via its DOI: $10.1037 /$ amp0000642

Author Statement: At the drafting of this manuscript, one author identified as Black American and one author identified as White American. Both authors contributed equally to this manuscript. 


\begin{abstract}
American racism is alive and well. In this essay, we amass a large body of classic and contemporary research across multiple areas of psychology (e.g., cognitive, developmental, social), as well as the broader social sciences (e.g., sociology, communication studies, public policy), and humanities (e.g., critical race studies, history, philosophy), to outline seven factors that contribute to American racism: 1) Categories, which organize people into distinct groups by promoting essentialist and normative reasoning, 2) Factions, which trigger ingroup loyalty and intergroup competition and threat, 3) Segregation, which hardens racist perceptions, preferences, and beliefs through the denial of intergroup contact, 4) Hierarchy, which emboldens people to think, feel, and behave in racist ways, 5) Power, which legislates racism on both micro and macro levels, 6) Media, which legitimizes overrepresented and idealized representations of White Americans while marginalizing and minimizing people of color, and 7) Passivism, such that overlooking or denying the existence of racism obscures this reality, encouraging others to do the same and allowing racism to fester and persist. We argue that these and other factors support American racism, and conclude with suggestions for future research, particularly in the domain of identifying ways to promote anti-racism.
\end{abstract}

Keywords: America, racism, hierarchy, anti-racism, development, social cognition 


\section{The Psychology of American Racism}

Martin Luther King Jr. dreamt of a United States in which children of all races could join hands as equals. Over half a century later, this dream has yet to become reality. As just a few examples, White students are perceived as more compliant than students of color, which decreases their likelihood of being expelled (Okonofua et al., 2016). White homeowners are perceived as cleaner and more responsible than homeowners of color, which increases their home equity (Bonam et al., 2016). And White criminals are perceived as less blameworthy than criminals of color, which decreases their likelihood of being executed (Baldus et al., 1998; Scott et al., 2017). Simply put, American racism is alive and well (Eberhardt, 2019). This essay integrates classic and contemporary research to ask a simple yet unresolved question: Why?

Of course, we are not the first to ask this question. Half a century ago, the American psychologist, Gordon Allport, published his seminal book, The Nature of Prejudice (1954), in which he amassed a large body of theoretical and empirical work to reveal the roots of racebased hostility. Since the publication of his book, research spanning multiple areas of psychology (e.g., cognitive, developmental, social), the broader social sciences (e.g., sociology, communication studies, public policy), and humanities (e.g., critical race studies, history, philosophy), each with their own methods and vantage points, has unearthed new ground to reveal the depth of these roots and the ways by which they are nourished. The primary purpose of this essay is to provide an introductory synthesis of these literatures to identify and discuss several key psychological factors that contribute to the perpetuation of American racism.

We begin by clarifying our terms and perspectives. First, informed by research, theory, and philosophical discourse, we define racism as a system of advantage based on race that is created and maintained by an interplay between psychological factors (i.e., biased thoughts, 
feelings, and actions) and sociopolitical factors (i.e., biased laws, policies, and institutions; Alexander, 2010; Bonilla-Silva, 1999; Kendi, 2016; Salter et al., 2018; Tatum, 1997).

Second, racism is not unique to the U.S., though we focus on the U.S. for three reasons: i) most psychological research on racism is conducted within the U.S., with few studies directly examining these issues internationally, ii) as U.S. citizens, we acknowledge our own positionality and limited insight into other contexts, and iii) a unique set of historical and sociocultural factors (e.g., the racial conquest and enslavement of persons of color), synergize to create a unique form of racism: American racism ${ }^{1}$ (Bourke, 2014; Henrich et al., 2010; Kendi, 2016). Thus, we focus on the U.S. as both a case study and as an indictment, in which the psychological underpinnings of racism are well-documented, as are the unjust consequences of racial hierarchy. We incorporate research from outside of the U.S. when appropriate, but do not make any claims about generalizability beyond the U.S.

Third, racism is not inborn (Kinzler \& Spelke, 2011); Americans become more or less inclined toward racism - or anti-racism - via a culmination of factors that are deeply woven into the fabric of U.S. society. Our view is that American racism is reinforced by all Americans, though to varying degrees. Just as citizens of capitalistic societies reinforce capitalism, whether they identify as capitalist or not, and whether they want to or not, citizens of racist societies reinforce racism, whether they identify as racist or not, and whether they want to or not.

Fourth, American racism advantages White Americans and disadvantages Americans of color (Tatum, 1997). Just as capitalism advantages the wealthy (e.g., those with the most resources can create and regulate norms, policies, and institutions that reinforce income

\footnotetext{
${ }^{1}$ We use the category "American" narrowly to refer to individuals in the U.S., and acknowledge that this category additionally includes Americans from other societies (e.g., Canada, Mexico, Brazil). Indeed, an important limitation to the existing literature is that it disproportionately focuses on U.S. society.
} 
inequality), American racism advantages White Americans (e.g., those with the most social and economic power can create and regulate norms, policies, and institutions that reinforce racial inequality). Critically, American racism also shapes, and is shaped by, dynamics within and between groups, and varies as a function of other social identities (e.g., racism oppresses women of color in ways that it does not oppress men of color; Comas-Díaz, 1994). These important intra-minority and intersectional components of American racism are truly deserving of their own review. Yet it is our view that they, too, reinforce a racial hierarchy that advantages White Americans (DiAngelo, 2012). This is not an indictment of any individual White American, per se. Rather, it is to illuminate a widespread and longstanding system of advantage. If that system is to be eradicated, all Americans, irrespective of their race, must acknowledge and understand the psychological and sociopolitical forces that reinforce it.

Finally, we do not review all of the factors that contribute to American racism, of which there were many to choose from. Our aim is to provide readers with a comprehensive yet straightforward overview of several of the major factors known or theorized to motivate racism as it plays out in the American cultural context. In doing so, we hope to bring together researchers and practitioners from diverse backgrounds and to provide them with a single essay that serves as a conceptual hub from which to overview the vast sea of accumulated knowledge, as well as a shared vantage point from which to explore new territory. We detail seven factors that contribute to American racism: 1) Categories, 2) Factions, 3) Segregation, 4) Hierarchy, 5) Power, 6) Media, 7) Passivism. We present these factors sequentially for conceptual clarity, but do not convey any ordering in terms of importance, prevalence, or developmental relevance. Indeed, the interactive relations between these factors contribute to the specific instantiation of American racism (e.g., media distorts categories, segregation reflects hierarchy, power enables 
passivism). We examine such interactions when salient, though space constraints preclude a full investigation. We now turn to seven factors that create and are created by American racism. ${ }^{2}$

\section{American Categories}

Humans are not born with racial categories in mind. They must be learned. According to Developmental Intergroup Theory (Bigler \& Liben, 2006), people acquire racial categories because they are often a) perceptually discriminable, b) disproportionate in size (i.e., categories with fewer members are more salient), c) explicitly and implicitly used (e.g., if groups are segregated, one may infer that there exist meaningful differences between them), and d) labeled (e.g., Asian, Black, Latinx, White) (see also Aboud, 1988; Cosmides et al., 2003; Hirschfeld, 1995). Racial categories are particularly important given that they are federally sanctioned (e.g., by the U.S. Census Bureau), easily employed by individuals, and because they directly tell people which racial categories to form.

Category labels can promote the belief that category members share an "essence" that grants them their identity (Rhodes \& Mandalaywala, 2017). As one example, Waxman (2010) introduced 4-year-old children in Chicago, Illinois, to White or Black individuals who were characterized by novel properties (e.g., likes to go glaving), and measured whether they inferred that others of the same race shared the property. Some children received labels (e.g., "This Wayshan likes to go glaving"), others did not (e.g., "This one likes to go glaving”). Particularly when individuals were labeled, children generalized the property more often to same-race individuals than to different-race individuals. Category labels are particularly powerful when presented via generics (e.g., "girls" instead of "this girl” or "these girls") given that generics

\footnotetext{
${ }^{2}$ We acknowledge the intersectional nature of racism both in the expression (e.g., differences in racist attitudes towards Black women and Black men, straight Black women and gay Black women) and formation (i.e., differences in the formation of racial attitudes across groups) of racial beliefs. We incorporate these concerns into our review when space permits, however, this important topic is truly deserving of its own extensive review.
} 
express generalizations about a kind (e.g., Birds lay eggs, Blacks are criminal), suggesting that a property is closely linked to a category (e.g., laying eggs is fundamental to birds, criminality is fundamental to Black people), despite there being considerable variation among category members (e.g., most birds do not lay eggs, including male birds, baby birds, and dead birds, and most Black people have clean criminal records). When preschoolers are introduced to social categories via generics instead of specific labels, they are more likely to infer that the category and property are linked, and that category membership entails an underlying essence (Rhodes et al., 2012). Notably, children do not thoughtlessly support essentialism across conceptual domains (e.g., artifacts, hair color), but do so for the properties their environment deems important (e.g., skin color in the U.S., religious attire in Israel; Diesendruck et al., 2013).

The link between category labels and essentialism is important for understanding racial stereotyping, prejudice, and discrimination (Rhodes \& Mandalaywala, 2017). Regarding stereotyping, because essentialism entails the belief that category members share properties, it predicts stereotyping among adults and children (Bastian \& Haslam, 2006; Pauker et al., 2016). Regarding prejudice, the belief that categories are natural supports the belief that category differences are natural, which supports the belief that racial hierarchies are natural (Mandalaywala et al., 2018). Regarding discrimination, essentialism predicts an exaggeration of the differences between social categories, which motivates people to avoid interracial contact, share fewer resources with outgroup members, and support boundary-enhancing policies (e.g., building a wall along the U.S.-Mexico border), revealing how categories shape legal and sociopolitical actions (Rhodes et al., 2018; Roberts et al., 2017b).

Category labels and generics additionally promote a descriptive-to-prescriptive tendency (i.e., believing that how a group is reflects how group members should be), which supports racial 
stereotyping and prejudice. Roberts et al. (2017a) introduced children to novel groups (i.e., Hibbles and Glerks) characterized by different behaviors (e.g., the kind of music they listened to). Children disapproved of non-conformity (e.g., a Glerk who listened to music more typical of Hibbles) and they justified their disapproval prescriptively (e.g., "Glerks shouldn't do that!"). Children were especially likely to show a descriptive-to-prescriptive tendency when they were introduced to groups via category labels or generics. Critically, children's negativity toward nonconforming Hibbles and Glerks predicts their future negativity toward non-conforming Black people and White people (e.g., a Black person who listened to music more typical of White people; Guo et al., 2019). Thus, labels and generics help children develop expectations about groups, which in turn license negativity toward individuals who challenge those expectations (e.g., a Black person who "acts" White; Durkee \& Williams, 2015).

\section{American Factions}

Individuals do not only learn about categories. They are also embedded within them. Almost 50 years ago, Henri Tajfel (1970) invited 64 boys into a lecture hall in Bristol, England and told them that he was interested in their visual judgments. Indeed, he showed them pictures with varying numbers of dots and asked them to estimate how many dots were in each picture. Tajfel then told the boys how well they estimated, but unbeknownst to them, what he told them was random. Irrespective of how the boys actually performed, they were randomly assigned to one of two groups: half were told that they were "overestimators" (i.e., that they overestimated the number of dots) whereas the others were told that they were "underestimators" (i.e., that they underestimated the number of dots). The boys were next brought into a separate room and asked to distribute money to anonymous ingroup and outgroup members. Surprisingly, the boys gave more money to members of their randomly determined ingroup. This experiment served as a 
foundational building block for research in Social Identity Theory (Tajfel \& Turner, 1979), and provided the first glimpse into what is now widely recognized as the Minimal Groups Phenomenon (MGP), which has been extensively replicated in the U.S. and abroad.

The MGP is rooted in two general motivations that are consequential (Dunham, 2018; Otten, 2016). First, people's positive perceptions of themselves often extend to positive perceptions of their group, which leads to an ingroup preference. Second, because people care about cooperative alliances, they intuitively interpret the groups that they are assigned to as requiring their cooperation, trust, and support, which leads to behaving in ways that benefit the ingroup and are consistent with ingroup norms. Even after being randomly assigned to a minimal group (e.g., via a shirt color or a coin-toss), children and adults feel and express positivity toward their ingroup, associate their ingroup with positivity, empathize with their ingroup, distribute resources in favor of their ingroup, and are more forgiving of and loyal to ingroup members.

In reality, people are not randomly assigned to minimal groups, but they are systematically assigned to socially constructed racial groups, and many of the effects that emerge in minimal groups contexts extend to race as well. Dunham (2011) had White adults judge whether racially ambiguous faces with happy or angry facial expressions were White or Black. White adults judged that happy faces were White (i.e., in their ingroup) and that angry faces were Black (i.e., in their outgroup), and participants' implicit racial preferences predicted their tendency to associate outgroups with anger. Critically, the desire to establish and maintain one's position within a group can also lead individuals to prioritize ingroup loyalty and group norms over moral concerns for fairness and inclusion (Killen et al., 2018). For example, children are less likely to include an outgroup member if they believe that members of their ingroup would disapprove (Hitti et al., 2019; Killen et al., 2002). Notably, ingroup biases and norms diverge as 
a function of power and hierarchy. For instance, White Americans show stronger ingroup preferences than Americans of color, who more often show preferences for the outgroup (Banaji \& Greenwald, 2013; Clark \& Clark, 1947). We return to this point in subsequent sections.

Of course, groups do not exist in isolation. They interact with other groups, which can result in group-based competition and conflict. Muzafer Sherif and colleagues (1954) invited 12year-old boys to a summer camp at Robbers Cave State Park in rural Oklahoma, and divided them into two groups. First, during the cooperation phase, each group was unaware of the other group's existence as they bonded with their ingroups (e.g., through team-building activities and discussion). During this phase, the groups established their own names (e.g., Eagles, Rattlers), norms (e.g., swimming, hiking), and symbols (e.g., clothing styles, flags). Second, during the competition phase, the two groups were introduced to one another and were brought into competition (e.g., sporting events), thereby inducing a sense of group threat. As conflict progressed, the groups began to insult, sabotage, and attack one another.

How are groups threatened and provoked into outgroup hostility? As reviewed by Riek, Mania, and Gaertner (2006), intergroup tensions are particularly likely to flare when groups experience threats to their self-image (i.e., esteem threats), uniqueness (i.e., distinctiveness threats), values and beliefs (i.e., symbolic threats), or goals and resources (i.e., realistic threats). Groups also experience threats rooted in intergroup anxiety (i.e., when people are uncertain of how intergroup interactions will play out, they often feel uncomfortable, uneasy, and threatened) and negative stereotypes about the outgroup (e.g., when people expect outgroups to behave negatively, they experience fear, anger, and threat; Richeson \& Shelton, 2007). These threats, different in nature, are rooted in three broader factors: 1) high-identification with one's ingroup, 2) limited or negative experiences with intergroup contact, and 3) hierarchical differences 
between groups, such that high-status groups are more likely to perceive outgroups as threatening than are low-status groups (see Segregation and Hierarchy sections).

\section{American Segregation}

In the U.S. and across the globe, racial segregation is pervasive at macro and micro levels (Lichter et al., 2016). Across and within countries, states, cities, and neighborhoods, White people are often residentially segregated from persons of color. For example, there is a lower proportion of White people living in the U.S. South compared to the U.S. North, in Northern Italy compared to Southern Italy, and in French metropolitan areas compared to French rural areas. At the micro level, in cities across the U.S. and Europe (e.g., Atlanta, Orlando, Brussels, London), there is a lower proportion of White people living in city centers than in peripheral regions. Notably, racial segregation tends to be higher in the U.S. than in Europe, which is a direct consequence of racist federal, state, and local policies (Kendi, 2016). Redlining, for example, systematically denied communities of color access to real estate and set the precedent for a range of federal and state policies that continue to disadvantage communities of color today (Rothstein, 2017). One result of these policies is racial segregation, which denies individuals the opportunities for interracial contact that could challenge racist perceptions, preferences, and beliefs (Paluck et al., 2018; Pettigrew \& Tropp, 2006; but see McKeown \& Dixon, 2017).

Regarding perceptions, a lack of interracial contact promotes perceptual narrowing - a phenomenon by which attention to perceptual information is at first broadly tuned, but then gradually becomes more selective across development (Lee et al., 2017). At birth, humans differentiate among faces of various races. With age, they remain able to differentiate among members of familiar races and become less able to differentiate among members of unfamiliar races. In other words, members of unfamiliar races begin to "look alike." Regarding preferences, 
a lack of interracial contact prevents children from developing familiarity with certain racial groups. At birth, infants attend equally to racial ingroup and outgroup members (measured via looking time). At 3-months, infants from racially diverse contexts maintain this proclivity, whereas those from racially homogenous contexts (e.g., Asian infants in China, White infants in Israel, Black infants in Ethiopia) begin to attend more to the groups they have the most contact with (i.e., their ingroup). Later in development, these visual preferences may contribute to social preferences, though more longitudinal research is needed to examine this directly (see Kinzler \& Spelke, 2011). Regarding beliefs, a lack of interracial contact promotes the belief that interracial relationships are undesirable, if not impossible. Illustrating this point, in one line of research, young children are shown pictures of ambiguous scenarios (e.g., two children of different races on a playground, with one child standing behind another child on the ground; McGlothlin \& Killen, 2010). What is ambiguous is whether the child standing pushed the child onto the ground, or whether they are helping them up. Children attending racially homogenous schools were more likely to interpret the ambiguous situation negatively (i.e., infer that the standing child pushed the other child), and were less likely to believe that children of different races could be friends, compared to children attending racially diverse schools, highlighting further how sociocultural contexts shape racist worldviews.

Critically, the biases that develop from a lack of interracial contact often favor White Americans. In the U.S., White Americans are a majority (77\%), whereas Latinx Americans (18\%), Black Americans (13\%), Asian Americans (6\%), and Native Americans (1\%) are all numerical minorities (U.S. Census Bureau, 2011). Accordingly, most Americans have more frequent contact with White people than with people of color, which results in more narrow perceptions, unfavorable preferences, and pessimistic beliefs about people of color (Lee et al., 
2017). In one classic study conducted in Baltimore, Maryland, Feinman and Entwisle (1976) found that, consistent with the notion that children are better able to recognize majority race faces, Black children were better at recognizing White faces than White children were at recognizing Black faces. This is consequential. In a criminal lineup, for instance, when a suspect is not the guilty party, perceptual narrowing for minority group members, paired with biased preferences and beliefs, increase the odds that an innocent suspect will be identified as the perpetrator, especially if that suspect is Black (Meissner \& Brigham, 2001). Indeed, in cases where felony convictions were overturned because of DNA evidence, a significant number of those convictions were the product of incorrect eyewitness identifications (Connors et al., 1996).

\section{American Hierarchy}

All societies are hierarchically ordered (Sidanius \& Pratto, 1999), and the reality that the U.S. is hierarchically ordered by race is uncontroversial. As noted above, White Americans are a numerical majority, making up roughly $77 \%$ of U.S. citizens (U.S. Census Bureau, 2011), yet they occupy the highest status positions at a vastly disproportionate rate. As just two examples, in $2018,97 \%$ of CEOs at Fortune 500 Companies were White (Fortune, 2018), as were 98\% of past U.S. Presidents. This hierarchy, rooted in American history and perpetuated by racist ideologies, practices, and policies (e.g., Plessy v. Ferguson, Brown v. Board of Education) rather than an inherent superiority of White Americans (Alexander, 2010; Bonilla-Silva, 1999; Williams, 1987), plays a critical role in the psychology of American racism, such that several cognitive biases and social ideologies reinforce the conception of White Americans as superior. Indeed, the status of "American" itself is readily granted to White Americans, and often denied to Americans of color, and particularly Asian and Latinx Americans (Harris et al., 2020; Zhou \& Cheryan, 2017). Because of this denial, immigrants and refugees face a host of explicit - and 
often societally sanctioned (see American Power section) - prejudice and discrimination, with long term consequences for health and wellbeing (Volkan, 2018).

Children are remarkably efficient at encoding and reinforcing social hierarchies (Pun et al., 2017). Doing so is adaptive; recognizing and supporting high-status individuals can increase one's own social status and access to resources. Thus, it is no surprise that young children and infants use a variety of cues to determine who is high-status (e.g., numerical and physical size, the ability to seize and control resources, and to give order and win conflicts; Pun et al., 2017; Gülgöz \& Gelman, 2017). Once status is encoded, children attribute its existence to dispositions (e.g., the high-status group must be more hard-working, dominant, and intelligent), rather than to structures (e.g., historical events and systems of oppression), and subsequently think, feel, and behave in ways that are hierarchy-reinforcing (e.g., they develop preferences for, attempt to affiliate with, and prefer to learn from high-status individuals; Hussak \& Cimpian, 2015; Roberts et al., 2019). These effects are especially pronounced when children themselves are high-status; children who are experimentally assigned to high-status groups are less willing to rectify unjust inequalities and are less able to empathize with others or see their perspectives (Rizzo, 2018; Rizzo \& Killen, 2018).

These effects extend beyond the laboratory. By 2042, Americans of color are projected to make up a majority of the U.S. population (U.S. Census Bureau, 2008). When White Americans (i.e., the high-status racial group in the U.S.) are made aware of this shifting racial landscape, they often feel that their status is under threat and show greater pro-White biases and support for conservative policies, parties, and political candidates (Craig et al., 2018). Indeed, several social psychological theories propose that high-status groups are motivated to maintain their high-status advantage by oppressing low-status groups (Verkuyten \& Yogeeswaran, 2017), and critical race 
theorists propose that White Americans are motivated to deny the existence of racism and White advantage, and the need for hierarchy-reducing policies (e.g., affirmative action and welfare), because doing so legitimizes their own social status (DiAngelo, 2012; Helms, 1992).

In addition to entering the world ready to encode status, Americans are bombarded with social ideologies that legitimize white supremacy from an early age. Some ideologies are subtle, like the myth of the Protestant Work Ethic (PWE), which suggests that hard work breeds success, despite the fact that success is more attainable for some than for others. Individuals who subscribe to the PWE are more likely to attribute hierarchies to dispositions (e.g., those at the top simply work harder than those at the bottom) rather than to biased social structures (e.g., de jure and de facto discrimination against lower status racial groups), and therefore oppose hierarchyreducing policies (Jost \& Hunyady, 2005; Sidanius \& Pratto, 1999). Other ideologies are explicit. For instance, the American practice of hypodescent (i.e., "the one drop rule") declared that children of one Black and one White parent were to be classified as Black and not White (i.e., in accordance with their low-status parentage). Hypodescent emerged in U.S. society in response to fears that "mulattoes" (i.e., referring to Black-White individuals) would blur the distinction between low-status slaves and high-status slavers, taint the purity of Whiteness, and threaten the legitimacy of slavery, and was therefore legislated across the nation (Davis, 1991). Hypodescent is no longer a federal practice (see Smith vs. the State of Louisiana), but it persists as a psychological practice: Black and White Americans categorize Black-White individuals as more Black than White (Ho et al., 2011; Roberts \& Gelman, 2015). Notably, hypodescent is particularly likely among White Americans high in essentialism, conservatism, and feelings of economic threat (Krosch \& Amodio, 2014; Ho et al., 2015). 
As another ideology, historians argue that the depiction of God as White became widespread in the U.S. after the U.S. Civil War granted full U.S. citizenship to Black Americans, resulting in White Americans fearing that Black Americans would seek retribution for slavery (Blum and Harvey, 2012). In the contemporary U.S., God is often conceptualized as White, which among Black and White Americans, adults and children, predicts evaluating White job candidates as particularly leadership worthy (Roberts et al., 2020a). Thus, Americans are bombarded with social myths that assert that high-status membership is at the same time earned by hard work, fixed at birth, and given by God.

\section{American Power}

White Americans are high in social status (i.e., evaluative reputation) and social power (i.e., ability to control and manipulate the social environment; Sidanius \& Pratto, 1999). Because White Americans have historically and contemporarily constituted a numerical majority, and occupied most positions of power, they have been able to establish societal norms (e.g., which accents are considered standard and who is allowed to participate in political elections), achieve goals (e.g., who is advantaged on "standardized" English tests and allowed to ascend to political positions of power), give orders (e.g., how English should be taught and which legislation to pass to mandate those teachings), control resources (e.g., establish educational institutions that shape curricula and financial institutions that shape economies), and dominate and exploit others (e.g., socialize racial minorities toward an "American" way of thinking, build hazardous-waste landfills that disproportionately affect communities of color; see Alexander, 2010; Baugh, 2000; Bullard, 2000; Duran \& Duran, 1995). Thus, white supremacy is deeply and intricately woven into the fabric of U.S. society (Salter et al., 2018). Indeed, even psychological research is shaped by racial hierarchy; from 1974 to 2018 , a disproportionate number of journal editors and authors 
were White, under which there have been fewer publications that highlight the importance of race and fewer participants of color (Roberts et al., 2020b).

How does power enable the perpetuation of white supremacy? At the micro level, parents control much of their children's lives, and children are particularly sensitive to what authority figures do and say when determining what is or is not appropriate (Rodríguez-García \& Wagner, 2009; Smetana, 1983). Indeed, a meta-analysis of 131 studies revealed that parents and children often have correlated group-based biases, particularly among high-status groups (e.g., White Americans; Degner \& Dalege, 2013). As a few examples, parents high in authoritarianism (i.e., a tendency to support norms and authority) are more likely to have children who trust authority figures (Reifen Tagar et al., 2014). Parents high in essentialism often use category labels and generics when referring to groups, which predicts children's own essentialism (Rhodes et al., 2012; Segall et al., 2015), and White parents who prefer hierarchy are more likely to have children who believe that Black people are subhuman (Costello \& Hodson, 2014). Also, if a child notices that their parent does not behave positively toward outgroup members, they subsequently disassociate from and feel negatively toward them (Skinner et al., 2017). Indeed, White Italian mothers' anti-Black attitudes have been found to predict their 3- to 6-year-old children's anti-Black attitudes (Castelli et al., 2009). Note that parents also control much of their children's environments, which is consequential. Parents who raise their children in mostly White neighborhoods and have mostly White social networks - all of which prevent children from benefitting from interracial contact - are more likely to have children with racist beliefs (Pahlke et al., 2012). Recall again that racial minorities, by virtue of living in a White-majority society, are in less of a position to avoid interracial contact - another product of racism. 
How parents talk (or do not talk) about race also matters. Racial socialization is the process by which parents transmit their beliefs about race to their children, through implicit, explicit, intentional, or accidental means (Hughes, 2003). White parents tend to adopt a colorblind ideology (i.e., believing that race does not matter and that conversations about race should be avoided), which leaves the observations and myths learned from the broader society unchallenged and reinforces the legitimacy of racial hierarchy (Katz, 2003; Pahlke et al., 2012). In contrast, parents of color often speak with their children about historical and structural inequalities, and about how to deal with racial biases that they might encounter in the real world, which challenges the observations and myths popularized by the broader, majority White, society (Neblett et al., 2009). Simply put, American society teaches American citizens that Whiteness is superior, and while parents of color often speak out against those lessons to prevent their children from internalizing them, White parents often remain silent about those lessons, allowing White children to internalize them.

At the macro level, nations are governed by individuals (e.g., Chancellors, Presidents), who shape their nation's norms, values, policies and institutions, and are therefore in a prime position from which to shape how their citizens view race. Below we detail two cases - one historical, one more recent; one foreign, one domestic - of individuals whose power corresponded with widespread racism across their societies. The purpose behind these selections (of which there are many to choose from) is not to draw connections between them, but rather, to focus on the similar processes by which they both might have shaped racism among their citizenry.

Perhaps the clearest example of how leadership can provoke racial biases is Adolf Hitler, the former "Führer" of Germany. Hitler's autobiography, Mein Kampf (1925), which is littered 
with clear-cut categories, generics, and essentialism, bombarded Nazi Germany with myths of an "Aryan race" with supposed "pure blood" and racial superiority that stemmed from "God's will". He systematically prevented interracial contact by sending German children to summer camps where they were indoctrinated with notions of Aryan supremacy, and by sending millions of Jewish people to concentration camps where they were forced into labor and killed. To this end, he ordered Jewish people to wear identifiable armbands, badges, and tattoos, and attributed the collapse of the German economy and potential end of the alleged Aryan race to Jewish people, thereby placing a premium on group hierarchy and threat. He also justified and reinforced notions of a natural and divine hierarchy that, if restored, would bring Germany back to its full potential. In doing so, he established a mass-production and distribution of Nazi propaganda (e.g., film, newspapers, radio) which ensured that the only exposure German citizens had to Jewish people was as inferior, nefarious, and subhuman (see Media section below). These and other calculated strategies enabled the most notorious demagogue of all time to provoke some of the greatest forms of racism known to humanity.

Donald J. Trump - the $45^{\text {th }}$ President of the United States - did not cause American racism. Yet his authoritarian, divisive, hierarchy-reinforcing, and racially prejudiced statements certainly corresponded with a resurgent following of White supremacists (Pettigrew, 2017). Trump proposed that the U.S. accept more people from countries like Norway, a predominantly White nation, and fewer people from countries like Haiti, a predominantly Black-Latinx nation, which he referred to as a "shithole" (Watkins \& Phillip, 2018). He suspended immigration from majority Muslim countries and prevented Mexicans, whom he referred to as rapists and "bad hombres," from entering the U.S. by funding a campaign to build a wall along the U.S.-Mexico border (Wolf, 2018). When Congress denied his request for complete funding for the wall, he 
declared immigration a national emergency (Trump, 2017). As such, it is no surprise that individuals high in racial prejudice, authoritarianism, social dominance orientation, dehumanization, and essentialism, and low in interracial contact, were particularly likely to support Trump's political platform (Choma \& Hanoch, 2017; Roberts et al., 2017b; Rothwell \& Diego-Rosell, 2016).

Only a few months after Trump's presidential inauguration, a group of White supremacists marched upon the University of Virginia chanting Nazi slogans, including “Jews will not replace us" and "blood and soil" (Rosenberg, 2017). Over the first three years of Trump's presidency, nation-wide hate crimes on the basis of race, religion, and sexual orientation all increased at a rapid rate (Eligon, 2018). By normalizing various racist behaviors (e.g., publicly insulting entire nations of color), Trump may indeed have inspired others to view such behaviors as acceptable, if not ideal (Roberts et al., 2017a). To our knowledge, no research to date has causally linked Trump's messages to nationwide increases in American racism (which could just as well have encouraged Trump's racist platform), though Trump's popularity and American racism have undeniably risen hand in hand, highlighting how psychological biases and sociocultural policies are inextricably linked.

\section{American Media}

In a seminal investigation of how media shapes social cognition, Albert Bandura and colleagues (1963) found that preschoolers from Palo Alto, California, who witnessed aggressive models on television subsequently mimicked that aggression themselves. Half a century later, research has elaborated on the factors implicated in this process, and how such processes might contribute to American racism. In the U.S., the average household has 2 televisions, the average citizen watches television for around 2.8 hours a day, around $84 \%$ of U.S. households own a 
computer, $77 \%$ of U.S. citizens own a cell phone with internet access, and $66 \%$ of U.S. citizens play video games (Pew Research Center, 2018; Statista, 2018; U.S. Bureau of Labor Statistics, 2018). How the media portrays (or does not portray) racial groups thus plays a pivotal role in reinforcing American racism. As two case studies, we consider how the American media portrays Native and Black Americans, relative to White Americans.

Between 2000 and 2010, White Americans made up 77\% of the U.S. population and Native Americans made up 1\% (U.S. Census Bureau, 2011). During that same time, White Americans made up roughly $83 \%$ of the characters on the most popular U.S. television shows, whereas Native Americans made up only .07\% (Tukachinsky et al., 2015). In the rare instance that Native Americans are represented, they are often depicted as stereotypical and historical figures (e.g., chiefs and princesses living in teepees, wearing feathers, riding horses; Fryberg \& Eason, 2017). Indeed, roughly $96 \%$ of online images of Native Americans depict historical representations (Leavitt et al., 2015). Such under- and misrepresentation conveys to viewers that Native Americans are stereotypical and no longer relevant to U.S. society. Because Native Americans make up roughly $1 \%$ of the U.S. population, the broader U.S. population is unlikely to have direct contact with Native Americans that could challenge such stereotypes.

Black Americans are less likely to be underrepresented on U.S. television; between 2000 and 2010, Black Americans made up 12\% of the U.S. population and 11\% of the regular characters on popular U.S. television shows (U.S. Census Bureau, 2011). Yet representation alone is only one piece; between 2003 and 2009, the proportion of high-status Black characters declined while the proportion of low-status Black characters tripled (Tukachinskly et al., 2015). Moreover, Dixon and Linz (2000) compared how often people were depicted as criminals and victims on television to actual crime reports and found that Black Americans were 
overrepresented as criminals and underrepresented as victims, whereas White Americans were underrepresented as criminals and overrepresented as victims. Viewers exposed to such portrayals are more likely to perceive Black people as criminal, report anti-Black attitudes, and support harsher criminal sentencing against Black people (Dixon, 2008; Tukachinsky et al., 2015). How American media portrays interracial interactions can further foster racism.

Weisbuch, Pauker, and Ambady (2009) examined 11 popular U.S. televisions shows, each with an average weekly audience of 9 million viewers. Characters showed more negative affect and body language toward Black characters than toward White characters of the same status, which increased participants' anti-Black attitudes.

The mis- and underrepresentation of racial minorities also exists in children's media. Bramlett-Solomon and Roeder (2008) found that in television commercials that targeted children, $93 \%$ of models were White whereas only 5\% were Black, and Black models were more likely to endorse low-cost and low-nutrition foods, thereby associating Blackness with poverty. These patterns also hold for America's popular children's books. Horning and colleagues (2016) found that $73.3 \%$ of story characters were White, $12.5 \%$ were anthropomorphized non-humans (e.g., rabbits, trucks), and only 7.6\% were Black and 0.9\% were Native Americans. Simply put, children's books are more likely to depict magical animals and artifacts than persons of color, suggesting to American children that talking rabbits and trucks are more important to American society. Indeed, children exposed to media consisting of predominantly White characters show greater levels of pro-White biases (Rizzo et al., 2019).

The media also fosters racial biases globally, particularly as it reinforces White standards of beauty. $\mathrm{Lu}$ (2009) found that the majority of Japanese anime characters, although intended to depict Asian characters, are perceived as White (in terms of their eye shape and skin and hair 
color). Li and colleagues (2008) found that in fashion magazines, 44\% of Korean ads and 54\% of Japanese ads depicted White models, and that the majority of Asian models had light-skin. Cosmetic companies use magazine and television ads to explicitly promote skin-lightening products, including White Perfect, sold by the world's largest cosmetics company, L'Oréal, and Fair \& Lovely, the best-selling skin-lightening product in India. These products are advertised globally as being able to give the skin a rejuvenated, brightened, natural, and pearl-like appearance, and individuals exposed to such ads report greater pro-White biases (Hunter, 2011).

\section{American Passivism}

Perhaps the most insidious component of American racism is passive racism; an apathy toward systems of racial advantage or denial that those systems exist. The American psychologist Beverly Tatum (1997) characterized racism as a moving walkway at an airport. Individuals who are actively racist, she argued, acknowledge racial hierarchy and the thoughts, feelings, and behaviors that reinforce it, and choose to walk - or run - along with it. Individuals who are passively racist, on the other hand, simply stand still and are moved along by the walkway. These individuals are not actively reinforcing racism, but they are nonetheless moving in the same direction as those who are. As an illustration, imagine two people playing a game of Monopoly. One player is allowed to collect $\$ 200$ whenever they pass go, build property wherever and whenever they want, and has a lower probability of drawing "Go to Jail" cards. The other player gets none of these luxuries. To rectify the system of advantage, one could restart the game, redefine the rules and redistribute the wealth, or stop playing the game altogether. To maintain the system, however, one could simply do nothing, or have both players follow the same rules moving forward (i.e., both players can now collect $\$ 200$ whenever they pass go, build property wherever and whenever they want, and have an equal probability of 
drawing "Go to Jail" cards), while leaving the unequal wealth distribution intact. Continuing to play under this guise of "equality" would not entail actively contributing to the system; it would entail passively maintaining it (i.e., one player is still advantaged). ${ }^{3}$

This scenario is in many ways analogous to American racism. For centuries, Americans of color were forced into free or cheap labor and denied the right to own businesses and properties, vote in political elections, and receive an education or fair employment. These realities, many of which persist today, continue to exert their effect. For example, in 1983, the median net worth of White Americans was $\$ 86,500$ higher than that of Black Americans, and by 2013, this difference rose to $\$ 133,000$ (Stepler, 2016). In 2015, the household median net worth for White Bostonians was \$247,000, whereas for Black Bostonians, it was \$8 (Johnson, 2017). In order to maintain such racism, individuals and institutions need only do nothing about it.

There are many pathways to passive racism. One is through ignorance (Nelson et al., 2013). Consider again the Monopoly scenario. If a child observes that one player has amassed greater wealth than the other, but is ignorant as to how this inequality came to be, they will likely have no reason to intervene and may even develop preferences for the wealthier player (Roberts et al., 2019). Yet if the child learns that there exists a structural reason for the inequality (i.e., racism), rather than a dispositional reason (i.e., the poor player's incompetence), they may perceive the game as unfair and in need of intervention (Rizzo et al., 2018). Indeed, U.S. adults who are ignorant about historical racism often deny contemporary racism (Nelson et al., 2013). A second (and related) pathway to passive racism is through denial. Both White Americans and Americans of color are more likely than ever to deny that racism is a major problem facing U.S. society, which reduces the motivation to support anti-racist policies, such as affirmative action or

\footnotetext{
${ }^{3}$ We thank Emile Bruneau for this clear illustration of racial inequality.
} 
the redistribution of wealth, and could promote the belief that racial inequality is justified by differences in effort (e.g., Black people should simply work harder; Kraus et al., 2019; Salter et al., 2018). A third pathway to passive racism is through the observation of inaction in others. Darley and Latané (1968) found that in emergencies, people are less likely to help others when surrounded by bystanders (i.e., individuals who observe but do not act). This phenomenon, recognized as the "bystander effect," is motivated by at least three psychological factors: 1) a feeling of less responsibility in the presence of others (i.e., diffusion of responsibility), 2) a fear that helping will elicit negative public judgment (i.e., evaluation apprehension), and 3) the belief that the situation must not really be an emergency if nobody is helping (i.e., pluralistic ignorance, see Hortensius \& de Gelder, 2018). These factors may apply to racism as well. Taking refuge in the comfort of other societal bystanders, fearing the ramifications of speaking out against racist institutions, and the denial of the full weight of the consequences of living in a racist society all passively reinforce racism. Those who observe others do nothing about racism may reason that there is no problem in need of solving, and may subsequently become passively, if not actively, racist. Note that White Americans who are passively racist are further advantaged by racism, whereas Americans of color who are passively racist continue to be disadvantaged by it.

\section{The Anti-Racist Road Ahead}

The literature on the psychology of American racism is longstanding, flourishing, and necessary, though by no means complete (see Richeson \& Sommers, 2016). In our review of the current literature, we identified how American Racism is organized by categories, triggered by factions, hardened by segregation, emboldened by hierarchy, legislated by power, legitimized by media, and overlooked by passivism. Yet a critical question moving forward is what role can psychology play in working against racism? That is, what is the psychology of anti-racism? We 
define anti-racism as a system of equity based on race that is created and maintained by a dynamic interplay between psychological factors (i.e., equitable thoughts, feelings, and actions) and sociopolitical factors (i.e., equitable laws, policies, and institutions), and we distinguish between identifying ways to reduce racism and identifying ways to promote anti-racism.

The literature on the psychology of American anti-racism is comparatively lacking, particularly among White Americans (see Anyiwo et al., 2018). Thus, rather than attempting to map out what an anti-racist road might look like for psychological research, we raise questions as to where an anti-racist road might begin: How often is anti-racism socialized in the household, and to what extent does this socialization vary as a function of race, class, experiences with racism, or other social realities? How can individuals and collectives, both advantaged and disadvantaged, be mobilized toward anti-racism in their everyday lives? What cognitive frameworks lead to a greater structural awareness, and can those frameworks be effectively nurtured in educational curricula? How can we promote anti-racism in young children, and how can we ensure that they remain anti-racist across development? How can individuals and collectives progress from active or passive racism to reactive anti-racism (i.e., challenging racism whenever it appears) to proactive anti-racism (i.e., challenging racism before it appears)? Indeed, anti-racism can only be active, and in order to understand it, we must actively examine it. One of the most important steps for future research will be to shift our attention away from how people become racist, and toward the contextual influences, psychological processes and developmental mechanisms that help people become anti-racist. In a state of increasing racial inequality, we hope to find future students and scholars, both in the U.S. and beyond, well-versed and embedded within a psychology of anti-racism. 


\section{References}

Aboud, F. E. (1988). Children and prejudice. New York, NY: B. Blackwell.

Alexander, M. (2010). The new Jim Crow: Mass incarceration in the age of colorblindness. New York, NY: New Press.

Allport, G. W. (1954). The nature of prejudice. Reading, MA: Addison-Wesley.

Anyiwo, N., Bañales, J., Rowley, S. J., Watkings, D. C. \& Richards-Schuster, K. (2018).

Sociocultural influences on the sociopolitical development of African American youth. (2018). Child Development Perspectives, 12, 165-170.

Baldus, C., Woodworth, G., Zuckerman, D., Weinder N. A., \& Broffit, B. (1998). Racial discrimination and the death penalty in the post-Furman era: An empirical and legal overview, with recent findings from Philadelphia. Cornell Law Review, 83, 1638-1770.

Banaji, M. R., \& Greenwald, A. G. (2013). Blindspot: Hidden biases of good people. New York, NY: Bantam Books.

Bandura, A., Ross, D., \& Ross, S. A. (1963). Imitation of film-mediated aggressive models. Journal of Abnormal and Social Psychology, 66, 3-11

Bastian, B., \& Haslam, N. (2006). Psychological essentialism and stereotype endorsement. Journal of Experimental Social Psychology, 42, 228-235.

Baugh, J. (2000). Linguistic Profiling. New York: Routledge Publishing.

Bigler, R. S., \& Liben, L. S. (2006). A developmental intergroup theory of social stereotypes and prejudice. Advances in Child Development and Behavior, 34, 39-90.

Blum, E. J., \& Harvey, P. (2012). The color of Christ: The son of God and the saga of race in America. Chapel Hill, NC: The University of North Carolina Press. 
Bonam, C. M., Bergsieker, H. B., \& Eberhardt, J. L., (2016) Polluting black space. Journal of Experimental Psychology: General, 145, 1561-1582.

Bonilla-Silva, E. (1999). The essential social fact of race. American Sociological Review, 64, 899-906.

Bourke, B. (2014). Positionality: Reflecting on the research process. The Qualitative Report, 19, 1-9.

Bramlett-Solomon, S., \& Roeder, Y. (2008). Looking at race in children's television: Analysis of Nickelodeon commercials. Journal of Children and Media, 2, 56-66.

Bullard, R. D. (2000). Dumping in Dixie: Race, Class, and Environmental Quality (3 ${ }^{\text {rd }}$ Edition). New York: Routledge.

Castelli, L., Zogmaister, C., \& Tomelleri, S. (2009). The transmission of racial attitudes within the family. Developmental Psychology, 45, 586-591.

Choma, B. L., \& Hanoch, Y. (2017). Cognitive ability and authoritarianism: Understanding support for Trump and Clinton. Personality and Individual Differences, 106, 287-291.

Cimpian, A., Brandone, A. C., \& Gelman, S. A. (2010). Generic statements require little evidence for acceptance but have powerful implications. Cognitive Science, 34, 1452-82.

Clark, K. B., \& Clark, M. P. (1947). Racial identification and preference among negro children. In T. M. Newcomb \& E. L. Hartley (Eds.), Readings in social psychology. New York, NY: Holt, Rinehart, and Winston.

Comas, Díaz, L. (1994). An integrative approach. In L. Comas-Díaz, \& B. Green (Eds.)., Women of color: Integrating ethnic and gender identities in psychotherapy (pp. 287-318). New York: Guilford. 
Connors, E., Lundregan, T., Miller, N., \& McEwen, T. (1996). Convicted by juries, exonerated by science. National Institute of Justice, Washington, DC: US Department of Justice.

Cosmides, L., Tooby, J., \& Kurzban, R. (2003). Perceptions of race. Trends in Cognitive Sciences, 7, 173-179.

Costello, K., \& Hodson, G. (2014). Explaining dehumanization among children: The interspecies model of prejudice. British Journal of Social Psychology, 53, 175-197.

Craig, M. A., Rucker, J. M., \& Richeson, J. A. (2018). The pitfalls and promise of increasing racial diversity: Threat, contact, and race relations in the 21 st century. Current Directions in Psychological Science, 27, 188-193.

Darley, J. M., \& Latané, B. (1968). Bystander intervention in emergencies: Diffusion of responsibility. Journal of Personality and Social Psychology, 8, 377-383.

Davis, F. J. (1991). Who is Black? One nation's definition. University Park, PA: Pennsylvania State University Press.

Degner, J., \& Dalege, J. (2013). The apple does not fall far from the tree, or does it? A metaanalysis of parent-child similarity in intergroup attitudes. Psychological Bulletin, 139, 1270-1304.

DiAngelo, R. (2012) What does it mean to be White? Developing White racial literacy. New York, NY: Peter Lang.

Diesendruck, G., Goldfein-Elbaz, R., Rhodes, M., Gelman, S., \& Neumark, N. (2013). Crosscultural differences in children's beliefs about the objectivity of social categories. Child Development, 84, 1906-1917. 
Dixon, T. L. (2008). Network news and racial beliefs: Exploring the connection between national television news exposure and stereotypical perceptions of African Americans. Journal of Communication, 58, 321-337.

Dixon, T. L., \& Linz, D. (2000). Overrepresentation and underrepresentation of African Americans and Latinos as lawbreakers on television news. Journal of Communication, 50, 131-154.

Dunham, Y. (2011). An angry = outgroup effect. Journal of Experimental Social Psychology, 47, 668-671.

Dunham, Y. (2018). Mere membership. Trends in Cognitive Sciences, 22, 780-793.

Duran, E., \& Duran, B. (1005). Native American postcolonial psychology. Albany: State University of New York Press.

Durkee, M. I., \& Williams, J. L. (2015). Accusations of acting White: Links to Black students' racial identity and mental health. Journal of Black Psychology, 41, 26-48.

Eberhardt, J. L. (2019). Biased: Uncovering the hidden prejudice that shapes what we see, think, and do. New York, NY: Penguin.

Eligon, J. (2018, November 13). Hate crimes increase for the third consecutive year, F.B.I. reports. The New York Times. Retrieved from https://www.nytimes.com/2018/11/13/us/hate-crimes-fbi-2017.html

Feinman, S., \& Entwisle, D. R. (1976). Children's ability to recognize other children's faces. Child Development, 47, 506-510.

Fortune. (2018). Fortune 500. Fortune. Retrieved from fortune.com/fortune500/list/

Fryberg, S. A., Eason, A. E. (2017). Making the invisible visible: Acts of commission and omission. Current Directions in Psychological Science, 26, 554-559. 
Gelman, S. A., \& Heyman, G. D. (1999). Carrot-eaters and creature-believers: The effects of lexicalization on children's inferences about social categories. Psychological Science, 10, 489-493.

Gelman, S. A., Ware, E. A., \& Kleinberg, F. (2010). Effects of generic language on category content and structure. Cognitive Psychology, 61, 273-301.

Guo, C., Wang, M., Van Wye, E., \& Roberts, S. O. (2019, March). Children's descriptive-toprescriptive tendency predicts prejudice, stereotyping, and race-based normativity. Paper presented at SRCD, Baltimore, Maryland.

Gülgöz, S., \& Gelman, S. A. (2017). Who's the boss? Concepts of social power across development. Child Development, 88, 946-963.

Harris, K., Armenta, A. D., Reyna, C., \& Zárate, M. A. (2020). Latinx Stereotypes: Myths and Realities in the Twenty-First Century. In J.T. Nadler \& E.C. Voyles (Eds.) Stereotypes: The Incidence and Impacts of Bias (pp. 128 - 143). Santa Barbara, CA: Praeger.

Helms, J. E. (1992). Why is there no study of cultural equivalence in standardized cognitive ability testing?. American Psychologist, 47, 1083-1101.

Henrich, J., Heine, S. J., \& Norenzayan, A. (2010). The weirdest people in the world? Brain and Behavioral Sciences, 33, 61-135.

Hirschfeld, L. A. (1995). Do children have a theory of race?. Cognition, 54, 209-252.

Hitler, A. (1925). Mein Kampf. Munich, Germany: Eher Verlag.

Hitti, A., Elenbaas, L., Noh, J. Y., Rizzo, M. T., Cooley, S., \& Killen, M. (2019). Expectations for cross-ethnic inclusion by Asian American children and adolescents. Group Processes \& Intergroup Relations. 
Ho, A. K., Roberts, S. O., \& Gelman, S. A. (2015). Essentialism and racial bias jointly contribute to the categorization of Multiracial individuals. Psychological Science, 26, 1639-1645.

Ho, A. K., Sidanius, J., Levin, D. T., \& Banaji, M. R. (2011). Evidence for hypodescent and racial hierarchy in the categorization and perception of biracial individuals. Journal of Personality and Social Psychology, 100, 492-506.

Horning, K. T., Lindgren, M. V., Schliesman, M. \& Townsend, E. M. (2016). A few observations: Literature in 2015. Cooperative Children's Book Center Choices 2016. Retrieved from http://ccbc.education.wisc.edu/books/choiceintro16.asp

Hortensius, R., \& de Gelder, B. (2018). From empathy to apathy: The bystander effect revisited. Current Directions in Psychological Science, 27, 249-256.

Hughes, D. (2003). Correlates of African American and Latino parents' messages to children about ethnicity and race: A comparative study of racial socialization. American Journal of Community Psychology, 31, 1-2.

Hunter, M. L. (2011). Buying racial capital: Skin-bleaching and cosmetic surgery in a globalized world. Journal of Pan African Studies, 4, 142-165.

Hussak, L. J., \& Cimpian, A. (2015). An early-emerging explanatory heuristic promotes support for the status quo. Journal of Personality and Social Psychology, 109, 735-752.

Johnson, A. (2017, December 11). That was no typo: The median net worth of black Bostonians really is $\$ 8$. The Boston Globe. Retrieved from https://www.bostonglobe.com/metro/2017/12/11/that-was-typo-the-median-net-worthblack-bostonians-really/ze $5 \mathrm{kxC} 1 \mathrm{j} J$ elx $24 \mathrm{M} 3 \mathrm{pugFFN} /$ story.html

Jost, J. T., \& Hunyady, O. (2005). Antecedents and consequences of system-justifying ideologies. Current Directions in Psychological Science, 14, 260-265. 
Katz, P. A. (2003). Racist or tolerant multiculturalists? How do they begin? American Psychologist, 58, 897-909.

Kendi, I. X. (2016). Stamped from the beginning: The definitive history of racist ideas in America. Nation Books.

Kendi, I. X. (2019). How to be an antiracist. One world.

Killen, M., Elenbaas, L., \& Rizzo, M. T. (2018). Young children's ability to recognize and challenge unfair treatment of others in group contexts. Human Development, 61, 281-96.

Killen, M., Lee-Kim, J., McGlothlin, H., Stangor, C., \& Helwig, C. C. (2002). How children and adolescents evaluate gender and racial exclusion. Monographs of the society for research in child development, 1-129.

Kinzler, K. D. \& Spelke, E. S. (2011). Do infants show social preferences for people differing in race? Cognition, 119, 1-9.

Kraus, M. W., Onyeador, I. N., Daumeyer, N. M., Rucker, J. M., \& Richeson, J. A. (2019). The misperception of racial economic inequality. Perspectives on Psychological Science, 14, 899-921.

Krosch, A. R., \& Amodio, D. M. (2014). Economic scarcity alters the perception of race. Proceedings of the National Academy of Sciences, 111, 9079-9084.

Lee, K., Quinn, P. C., \& Pascalis, O. (2017). Face race processing and racial bias in early development: A perceptual-social linkage. Current Directions in Psychological Science, 26, 256-262.

Li, E. P. H., Min, H. J., Belk, R. W., Kimura, J., \& Bahl, S. (2008). Skin lightening and beauty in four Asian cultures. In A. Y. Lee \& D. Soman (Eds.), NA-Advances in consumer research volume 35 (pp. 444-449). Duluth, MN: Association for Consumer Research. 
Lichter, D. T., Parisi, D., \& De Valk, H. (2016). Residential segregation. Pathways, 65-74.

Liebler, C. A. (2016). On the boundaries of race: Identification of mixed-heritage children in the United States, 1960 to 2010. Sociology of Race and Ethnicity, 2, 548-568.

Lu, A. S. (2009). What race do they represent and does mine have anything to do with it? Perceived racial categories of anime characters. Animation, 4, 169-190.

Mandalaywala, T. M., Amodio, D. M., \& Rhodes, M. (2018). Essentialism promotes racial prejudice by increasing endorsement of social hierarchies. Social Psychological and Personality Science, 9, 461-469.

McGlothlin, H., \& Killen, M. (2010). How social experience is related to children's intergroup attitudes. European Journal of Social Psychology, 40, 625-634.

McKeown, S. \& Dixon, J. (2017). The "contact hypothesis": Critical reflections and future directions. Personality and Social Psychology Compass, 11, 1-13.

Meissner, C. A., \& Brigham, J. C. (2001). Thirty years of investigating the own-race bias in memory for faces: A meta-analytic review. Psychology, Public Policy, and Law, 7, 3.

Neblett, E. W. Jr., Smalls, C. P., Ford, K. R., Nguyen, H. X., \& Sellers, R. (2009). Racial socialization and racial identity: African American parents' messages about race as precursors to racial identity. Journal of Youth and Adolescence, 38, 189-203.

Nelson, C. A. (2013). Some thoughts on the development and neural bases of face processing. In M.R. Banaji \& S. A. Gelman (Eds.), Navigating the social world: What infants, children, and other species can teach us (pp. 166-169). New York, NY: Oxford University Press.

Nelson, J. C., Adams, G., \& Salter, P. S. (2013). The Marley hypothesis: Denial of racism reflects ignorance of history. Psychological Science, 24, 213-218. 
Okonofua, J. A., Walton, G. M., \& Eberhardt, J. L. (2016). A vicious cycle: A socialpsychological account of extreme racial disparities in school discipline. Perspectives on Psychological Science, 11, 381-398.

Otten, S. (2016). The Minimal Group Paradigm and its maximal impact in research on social categorization. Current Opinion in Psychology, 11, 85-89.

Pahlke, E., Bigler, R. S., \& Suizzo, M. A. (2012). Relations between colorblind socialization and children's racial bias: Evidence from European American mothers and their preschool children. Child Development, 83, 1164-1179.

Paluck, E. L., Green, S. A., Green, D. P. (2018). The contact hypothesis re-evaluated. Behavioural Public Policy, 1-30.

Pauker, K., Xu, Y., Williams, A., \& Biddle, A. M. (2016). Race essentialism and social contextual differences in children's racial stereotyping. Child Development, 87, 1409-22.

Pettigrew, T. F. (2017). Social psychological perspectives on Trump supported. Journal of Social and Political Psychology, 5, 107-116.

Pettigrew, T. F., \& Tropp, L. R. (2006). A meta-analytic test of intergroup contact theory. Journal of Personality and Social Psychology, 90, 751.

Pew Research Center (2018, February 5). Mobile fact sheet. Pew Research Center. Retrieved from http://www.pewinternet.org/fact-sheet/mobile/

Pun, A., Birch, S. A., \& Baron, A. S. (2017). Foundations of reasoning about social dominance. Child Development Perspectives, 11, 155-160.

Reifen Tagar, M., Federico, C. M., Lyons, K. E., Ludeke, S., \& Koenig, M. A. (2014). Heralding the authoritarian? Orientation toward authority in early childhood. Psychological Science, 25, 883-892. 
Rhodes, M., Leslie, S. J., Saunders, K., Dunham, Y., \& Cimpian, A. (2018). How does social essentialism affect the development of intergroup relations? Developmental Science, 21, e12509.

Rhodes, M., \& Mandalaywala, T. M. (2017). The development and developmental consequences of social essentialism. Wiley Interdisciplinary Reviews: Cognitive Science, 8, e1437.

Rhodes, M., Leslie, S. J., \& Tworek, C. M. (2012). Cultural transmission of social essentialism. Proceedings of the National Academy of Sciences, 109, 13526-13531.

Richeson, J. A., \& Shelton, J. N. (2007). Negotiating interracial interactions: Costs, consequences, and possibilities. Current Directions in Psychological Science, 16, 316-20.

Richeson, J. A., \& Sommers, S. R. (2016). Toward a social psychology of race and race relations for the twenty-first century. Annual Review of Psychology, 67, 439-463.

Riek, B. M., Mania, E. W., \& Gaertner, S. L. (2006). Intergroup threat and outgroup attitudes: A meta-analytic review. Personality and Social Psychology Review, 10, 336-353.

Rizzo, M. T., Elenbaas, L., \& Vanderbilt, K. E. (2018). Do children distinguish between resource inequalities with individual versus structural origins? Child Development, 2, 439-455.

Rizzo, M. T., Green, E., Dunham, Y., Bruneau, E., \& Rhodes, M. (2019). The development of racial bias: Parental and media influences. Poster presented at the biennial meeting of the Cognitive Development Society, Louisville, KY.

Rizzo, M. T., \& Killen, M. (2018). How social status influences our understanding of others’ mental states. Journal of Experimental Child Psychology, 169, 30-41.

Rizzo, M. T. (2018). Children's developing conceptions of fairness: The role of status in children's responses to inequalities (Unpublished doctoral dissertation). University of Maryland, College Park, USA. 
Roberts, S. O., \& Gelman, S. A. (2015). Do children see in Black and White? Children's and adults' categorizations of multiracial individuals. Child Development, 86, 1830-1847.

Roberts, S. O., Ho, A. K., \& Gelman, S. A. (2017a). Group presence, category labels, and generic statements influence children to treat descriptive group regularities as prescriptive. Journal of Experimental Child Psychology, 158, 19-31.

Roberts, S. O., Ho, A. K., Gülgöz, S., Berka, J., \& Gelman, S. A. (2019). The role of group status and group membership in the practice of hypodescent. Child Development. Advanced online publication.

Roberts, S. O., Ho, A. K., Rhodes, M., \& Gelman, S. A. (2017b). Making boundaries great again: Essentialism and support for boundary-enhancing initiatives. Personality and Social Psychology Bulletin, 43, 1643-1658.

Roberts, S. O., Weisman, K, Lane, J. D., Williams, A., Camp, N. P., Wang, M., Robison, M., Sanchez, K., \& Griffiths, C. (2020a). God as White man: A psychological barrier to conceptualizing Black people and women as leadership worth. Journal of Personality and Social Psychology. Advanced online publication.

Roberts, S. O., Baraket-Shavit, C., Dollins, F. A., Goldie, P. D., \& Mortenson, E. (2020b). Racial inequality in psychological research: Trends of the past and recommendations for the future. Perspectives on Psychological Science. Manuscript accepted for publication.

Rodríguez-García, J. M., \& Wagner, U. (2009). Learning to be prejudiced: A test of unidirectional and bidirectional models of parent-offspring socialization. International Journal of Intercultural Relations, 33, 516-523.

Rosenberg, Y. (2017, August 14). 'Jews will not replace us': Why white supremacists go after Jews. Washington Post. Retrieved from https://www.washingtonpost.com/news/acts-of- 


\section{faith/wp/2017/08/14/jews-will-not-replace-us-why-white-supremacists-go-after-} jews/?noredirect $=$ on\&utm term $=.0 \mathrm{df6} 612 \mathrm{e} 584 \mathrm{dd}$

Rothstein, R. (2017). The Color of Law. New York: Liverlight Publishing.

Rothwell, J. T., \& Diego-Rosell, P. (2016). Explaining nationalist political views: The case of Donald Trump. SSRN Electronic Journal.

Salter, P. S., Adams, G., \& Perez, M. J. (2018). Racism in the structure of everyday worlds: A cultural-psychological perspective. Current Directions in Psychological Science,27,150-5

Scott, K., Ma, D. S., Sadler, M. S., \& Correll, J. (2017). A social scientific approach toward understanding racial disparities in police shooting: Data from the Department of Justice (1980-2000). Journal of Social Issues, 73, 701-722.

Segall, G., Birnbaum, D., Deeb, I., \& Diesendruck, G. (2015). The intergenerational transmission of ethnic essentialism: How parents talk counts the most. Developmental Science, 18, 543-555.

Sherif, M., Harvey, O. J., White, B. J., Hood, W. R., \& Sherif, C. (1954). Experimental study of positive and negative intergroup attitudes between experimentally produced groups: Robbers cave experiment. Norman: University of Oklahoma.

Sidanius, J., \& Pratto, F. (1999). Social dominance: An intergroup theory of social hierarchy and oppression. New York, NY: Cambridge University Press.

Skinner, A. L., Meltzoff, A. N., \& Olson, K. R. (2017). "Catching” social bias: Exposure to biased nonverbal signals creates social biases in preschool children. Psychological Science, 28, 216-224.

Smetana, J. (1983). Social-cognitive development: Domain distinctions and coordinations. Developmental Review, 3, 131-147. 
Statista (2018). U.S. gamers - statistics \& facts. Statista. Retrieved from https://www.statista.com/topics/3070/us-gamers/

Stepler, R. (2016, June 27). 5 key takeaways about views of race and inequality in America. Pew Research Center Fact Tank. Retrieved from http://www.pewresearch.org/fact$\underline{\operatorname{tank} / 2016 / 06 / 27 / \text { key-takeaways-race-and-inequality/ }}$

Tajfel, H. (1970). Experiments in intergroup discrimination. Scientific American, 223, 96-103. Tajfel, H., \& Turner, J. C. (1979). An integrative theory of social conflict. The social psychology of intergroup relations, 2, 33-47.

Tatum, B. D. (1997). Why are all the Black kids sitting together in the cafeteria? And other conversations about race. New York, NY: Basic Books.

Trump, D. J. (2017, January 27). Executive order protecting the nation from foreign terrorist entry into the United States. White House Executive Orders. Retrieved from https://www.whitehouse.gov/presidential-actions/executive-order-protecting-nation$\underline{\text { foreign-terrorist-entry-united-states/ }}$

Tukachinsky, R., Mastro, D., \& Yarchi, M. (2015). Documenting portrayals of race/ethnicity on primetime television over a 20-year span and their association with national-level racial/ethnic attitudes. Journal of Social Issues, 71, 17-38.

U.S. Bureau of Labor Statistics. (2018, June 28). American time use survey summary. United States Department of Labor Economic News Release. Retrieved from https://www.bls.gov/news.release/atus.nr0.htm

U.S. Census Bureau. (2008). An older and more diverse nation by midcentury. United States Census Bureau. Retrieved from http://www.census.gov/ newsroom/releases/archives/population/cb08-123.html 
U.S. Census Bureau. (2011). American community survey (ACS). United States Census Bureau. www.census.gov/programs-surveys/acs/guidance/comparing-acs-data/2011.html

Verkuyten, M., \& Yogeeswaran, K. (2017). The social psychology of intergroup toleration: A roadmap for theory and research. Personality and Social Psychology Review, 21, 72-96.

Volkan, V. D. (2018). Immigrants and refugees: Trauma, perennial mourning, prejudice, and border psychology. Routledge.

Watkins, E., \& Phillip, A. (2018, January 12). Trump decries immigrants from 'shithole countries' coming to US. CNN Politics. www.cnn.com/2018/01/11/politics/immigrants$\underline{\text { shithole-countries-trump/index.html }}$

Waxman, S. R. (2010). Names will never hurt me? Naming and the development of racial and gender categories in preschool-aged children. European Journal of Social Psychology, 40, 593-610.

Weisbuch, M., Pauker, K., \& Ambady, N. (2009). The subtle transmission of race bias via televised nonverbal behavior. Science, 326, 1711-1714.

Williams, C. (1987). The destruction of black civilization: Great issues of a race from 4500 BC to 2000 AD. Chicago, IL: Third World Press.

Wolf, Z. B. (2018, April 6). Trump basically called Mexicans rapists again. CNN Politics. www.cnn.com/2018/04/06/politics/trump-mexico-rapists/index.html

Zhou, L. X., \& Cheryan, S. (2017). Two axes of subordination: A new model of racial position. Journal of Personality and Social Psychology, 112, 696-717. 